\title{
Deteksi Zona Rawan Tsunami Pesisir Kota Bandar Lampung Menggunakan Data Geospasial Berbasis Sistem Informasi Geografis
}

\section{Detection Of Tsunami Prone Areas Of Bandar Lampung Costal Region Using Geospacial Data Based On Geographic Infromation System}

\author{
Iskandar Zulkarnain, I Gde Darmaputra, Aniessa Rinny A. \\ Jurusan Teknologi Pertanian Politeknik Negeri Lampung \\ Jl. Soekarno-Hatta No. 10 Rajabasa, Bandar Lampung,35144 \\ e-mail : iskandar160575@polinela.ac.id
}

\begin{abstract}
The Bandar Lampung coastal area naturally has the potential of a tsunami hazard. Historically the coastal area of Bandar Lampung City had been hit by a tsunami with a height of 10-30 meters in 1883 when the eruption of Mount Krakatau occurred. The partial collapse of Mount Krakatau, which occurred at the end of 2018, also had a tidal wave impact as high as 1-2 meters in the Bandar Lampung coastal area. This study aims to produce Thematic Maps of Tsunami Hazard Zones in the Coastal Areas of Bandar Lampung City as a source of information for the community and stakeholders. The method used is spatial analysis with GIS through the overlay method. The result shown that eight sub district in Bandar Lampung City are prone to tsunami hazards with risk categories up to very high risk categories.
\end{abstract}

Keywords: tsunami, tematic maps, Bandar Lampung City

Naskah ini diterima pada tanggal 7 Oktober 2020, direvisi pada tanggal 21 Oktober 2020 dan disetujui untuk diterbitkan pada tanggal 15 Desember 2020

\section{PENDAHULUAN}

Tsunami merupakan salah satu potensi bencana alam yang selalu mengancam penduduk yang tinggal di wilayah pesisir. Bahaya yang tidak dapat diprediksi dan daya rusak yang besar ini membuat bencana tsunami ini harus diperhitungkan agar dapat mengurangi kerugian baik material maupun korban jiwa (Subardjo P dan Ario R 2015). Kota Bandar Lampung merupakan salah satu daerah yang memiliki tingkat resiko terhadap bahaya tsunami. Kondisi ini disebabkan secara geologis Provinsi Lampung terletak di zona subduksi Lempeng Indo-Australia dan Lempeng Eurasia, selain itu keberadaan Gunung Krakatau di Selat Sunda dan Sesar Semangko yang membentang dari Propinsi Aceh hingga Propinsi Lampung menjadi alasan lain mengapa daerah ini sangat rawan bencana tsunami (Dewi C et al, 2014).

Secara historis, wilayah pesisir Kota Bandar Lampung pernah dilanda tsunami dengan ketinggian10-30 meter pada tahun 1883 pada saat Gunung Krakatau meletus. Kemudian di 
penghujung tahun 2018 ketika sebagian tubuh Gunung Krakatau runtuh, terjadi pula gelombang pasang setinggi 1-2 meter di wilayah pesisir Kota Bandar Lampung. Untuk mengantisipasi dampak kemungkinan bahaya tsunami di Kota Bandar Lampung, diperlukan upaya pengurangan risiko guna mengurangi kerugian akibat bahaya tsunami.

Upaya pengurangan risiko tsunami non struktural dapat dilakukan melalui edukasi dan sosialisasi kepada masyarakat tentang bahaya tsunami. Informasi yang memadai tentang risiko bencana tsunami dapat disediakan melalui analisis yang komprehensif menggunakan Sistem Informasi Geografis (SIG) (Bambang, dkk. 2007 dalam Santius, 2015). Dengan pendekatan GIS, penanganan kebutuhan seperti peringatan dini dapat menjadi salah satu alternatif bagi Pemerintah Kota Bandar Lampung, dengan memberikan informasi data geospasial tematik wilayah mana yang memiliki kerentanan tinggi atau sangat tinggi terhadap bahaya tsunami dalam bentuk peta tematik zona kerentanan bahaya tsunami. Berdasarkan uraian diatas maka penelitian ini dilakukan untuk 1) Menentukan Zona Daerah Rawan Tsunami di Wilayah Pesisir Kota Bandar Lampung, 2) Membuat Peta Tematik Zona Rawan Bencana Tsunami di Wilayah Pesisir Kota Bandar Lampung.

\section{Metodologi Penelitian}

Penelitian ini merupakan studi analisis geospastial dengan menggunakan data dari delapan peta tematik yang digunakan sebagai parameter dalam penentuan zona daerah rawan tsunami. Rencana kegiatan penelitian ini disajikan pada Gambar 1.

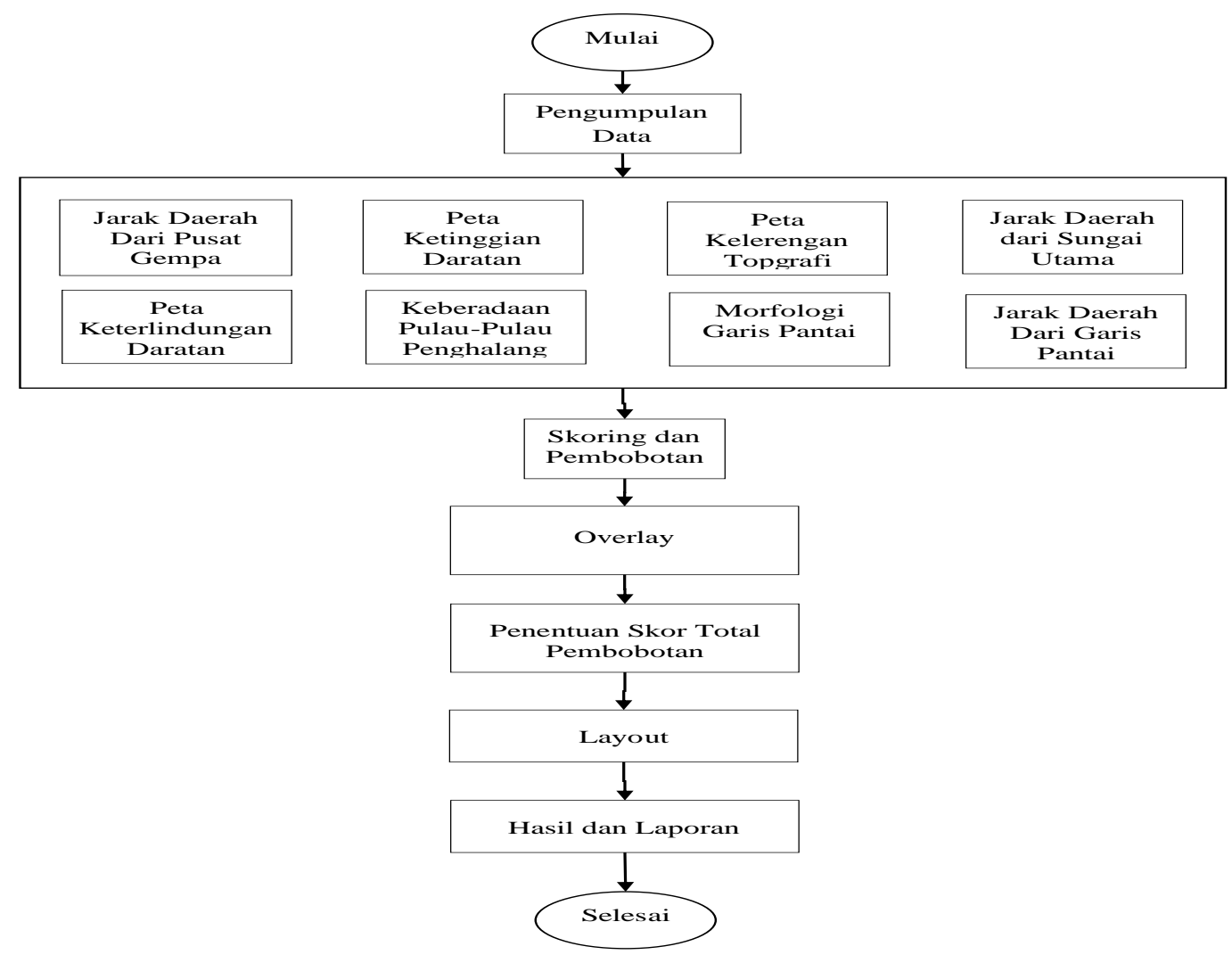

Gambar 1. Diagram Alir kegiatan Penelitian 


\section{Penentuan Skor Parameter}

Menurut Subarjo, Peta (2015) parameter kerentanan wilayah terhadap bencana tsunami ditentukan oleh beberapa hal yaitu jarak dari sumber tsunami, elevasi daratan, topografi lereng, jarak dari sungai utama, perlindungan lahan, keberadaan pulau penghalang, morfologi pantai, dan jarak dari garis pantai.

\section{a. Jarak Dari Pusat Gempa.}

Jarak dari sumber gempa menjadi parameter penentu dalam penentuan zona bahaya tsunami dengan bobot 10\%. Berdasarkan sumber yang diperoleh dari Subardjo, dkk (2015) Klasifikasi Jarak daratan dari Sumber Gempa dapat dilihat pada Tabel 1.

Tabel 1. Jarak dari pusat gempa

\begin{tabular}{ccccc}
\hline No & Jarak $(\mathrm{Km})$ & Skor & Bobot & Skor $x$ Bobot \\
\hline 1 & $0-150$ & 1 & 10 & 10 \\
\hline 2 & $151-260$ & 2 & 10 & 20 \\
\hline 3 & $>260$ & 3 & 10 & 30 \\
\hline
\end{tabular}

Identifikasi terhadap jarak wilayah daratan Kota Bandar Lampung dengan asumsi episentrum gempa berada di lokasi Gunung Krakatau, menunjukkan bahwa seluruh Kota Bandar Lampung terletak pada jarak kurang dari $150 \mathrm{~km}$, sehingga skor x bobot yang diperoleh untuk seluruh wilayah Bandar Lampung adalah 10. Peta tematik terhadap hal ini sebagai mana ditunjukkan pada Gambar 2.

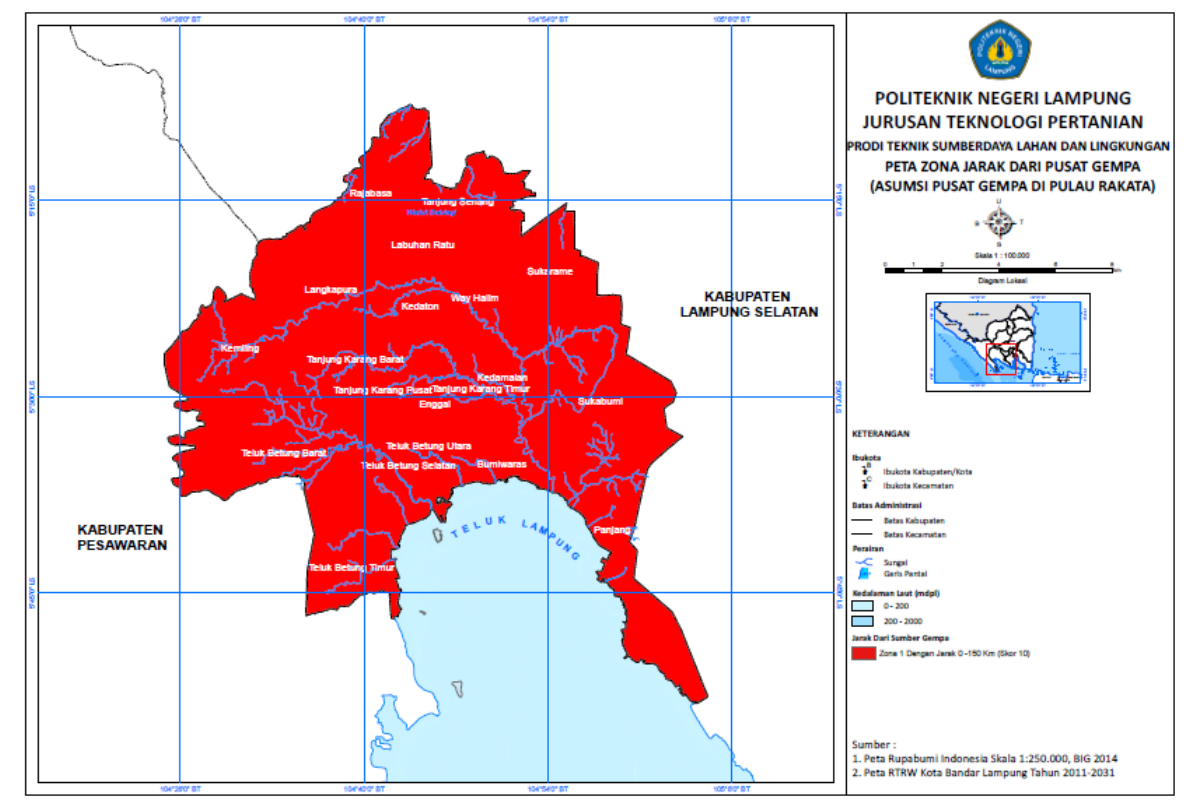

Gambar 2. Peta Tematik Skor x Bobot Berdasarkan Jarak dari Sumber Gempa 
b. Elevasi Tanah.

Elevasi/ketinggian tanah menjadi parameter penentu dalam penentuan zona rawan tsunami dengan bobot $15 \%$. Berdasarkan sumber yang diperoleh dari Subardjo, dkk (2015) Klasifikasi elevasi lahan dapat dilihat pada Tabel 2.

Tabel 2. Elevasi Tanah

\begin{tabular}{ccccc}
\hline No & Elevasi $(\mathrm{m})$ & Skor & Bobot & Skor $\times$ Bobot \\
\hline 1 & $0-5$ & 1 & 15 & 15 \\
\hline 2 & $6-10$ & 2 & 15 & 30 \\
\hline 3 & $11-15$ & 3 & 15 & 45 \\
\hline 4 & $16-20$ & 4 & 15 & 60 \\
\hline 5 & $>20$ & 5 & 15 & 75 \\
\hline
\end{tabular}

Identifikasi terhadap ketinggian lahan di wilayah Kota Bandar Lampung di dapat variasi ketinggian lahan sebagaimana di sajikan pada Tabel 3.

Tabel 3. Variasi Ketinggian Lahan Kota Bandar Lampung

\begin{tabular}{cccc}
\hline No & Elevasi Tanah $(\mathrm{m})$ & Luas Area $(\mathrm{Ha})$ & Persentase \\
\hline 1 & $0-5$ & 381,56 & 1,93 \\
\hline 2 & $6-10$ & 830,19 & 4,21 \\
\hline 3 & $11-15$ & 273,38 & 1,39 \\
\hline 4 & $16-20$ & 169,36 & 0,86 \\
\hline 5 & $>20$ & $18.067,00$ & 91,61 \\
\hline
\end{tabular}

Daerah dengan ketinggian 0-5 m terletak di bagian selatan Kota Bandar Lampung yang meliputi sebagian Kecamatan Panjang, Bumi Waras, Teluk Betung Timur, Teluk Betung Barat dan Teluk Betung Selatan.

Sedangkan daerah dengan ketinggian 6-10 m dari 11-15 m dan 16-20 m, terletak di bagian selatan kota Bandar Lampung yang meliputi sebagian Kecamatan Panjang, Bumi Waras, Teluk Betung Timur, Teluk Betung Utara, Teluk Betung Barat, Teluk Betung Selatan dan Sukabumi.

Kemudian daerah dengan ketinggian lebih dari $20 \mathrm{~m}$ terletak di bagian utara kota Bandar Lampung yang meliputi sebagian Kecamatan Kemiling, Sukarame, Tanjung Senang, Rajabasa, Tanjung Karang Pusat, Tanjung Karang Barat, Labuhan Ratu, Langkapura, Kedaton, Way Halim, Tanjung Karang Timur, Kedamaian, Enggal, Sebagian Sukabumi, sebagian Teluk Betung Barat, Sebagian Teluk Betung Utara, Sebagian Teluk Betung Selatan, sebagian Teluk Betung Timur dan sebagian Panjang.

Hasil skor peta tematik elevasi lahan wilayah Kota Bandar Lampung ditunjukkan pada Gambar 3. 


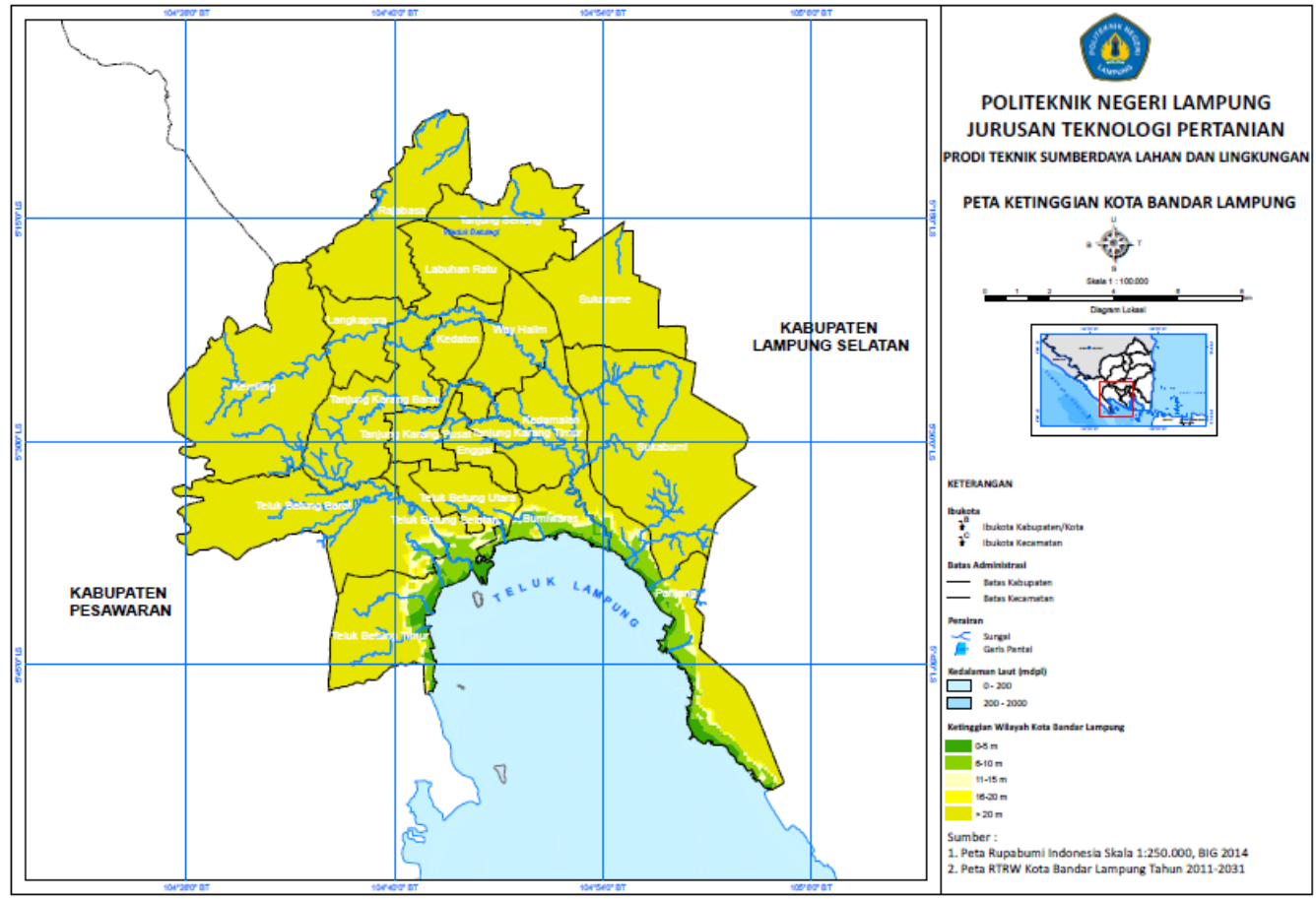

Gambar 3. Peta Tematik Skor x Bobot Berdasarkan Elevasi/Ketinggian Lahan

c. Kelerengan Topografi.

Kelerengan topografi menjadi parameter penentu dalam penentuan zona bahaya tsunami dengan bobot $10 \%$. Berdasarkan sumber yang diperoleh dari Subardjo, dkk (2015) Klasifikasi kemiringan topografi dapat dilihat pada Tabel 4.

Tabel 4. Kelerengan Topografi

\begin{tabular}{ccccc}
\hline No & Slope (\%) & Skor & Bobot & Skor $x$ Bobot \\
\hline 1 & $0-2$ & 1 & 10 & 10 \\
\hline 2 & $2-6$ & 2 & 10 & 20 \\
\hline 3 & $6-13$ & 3 & 10 & 30 \\
\hline 4 & $13-20$ & 4 & 10 & 40 \\
\hline 5 & $20-55$ & 5 & 10 & 50 \\
\hline 6 & $>55$ & 6 & 10 & 60 \\
\hline
\end{tabular}

Variasi kelerengan topografi tersebar secara merata di seluruh wilayah kota bandar lampung. Peta tematik kemiringan topografi wilayah Kota Bandar Lampung disajikan pada Gambar 4. 


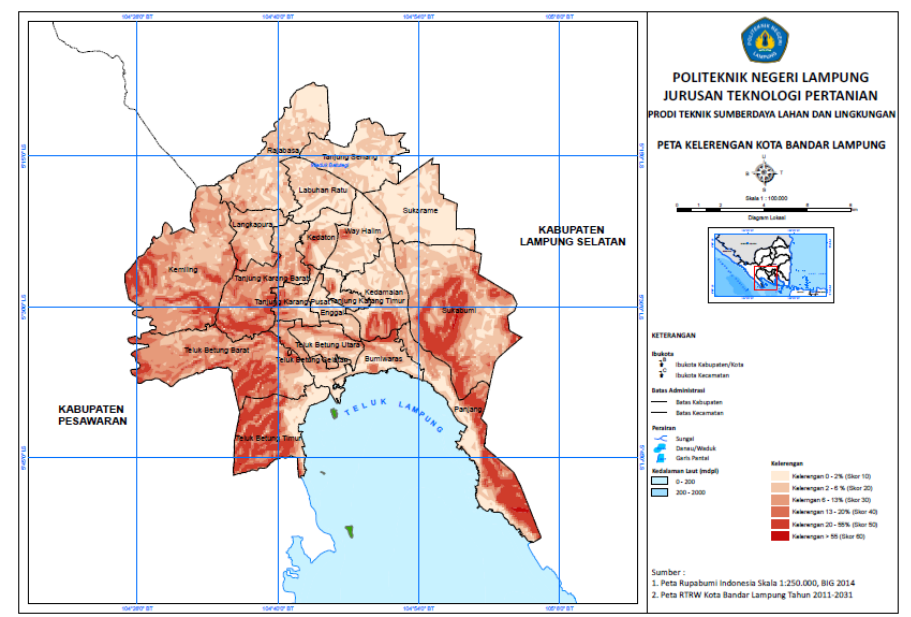

Gambar 4. Peta Tematik Skor x Bobot Berdasarkan Kelerengan Topografi

d. Jarak dari Sungai Utama.

Jarak dari sungai utama menjadi parameter penentu dalam penentuan zona rawan tsunami dengan bobot $10 \%$. Berdasarkan sumber yang diperoleh dari Subardjo, dkk. (2015) Klasifikasi jarak dari sungai utama dapat dilihat pada Tabel 5.

Tabel 5. Jarak dari Sungai Utama

\begin{tabular}{ccccc}
\hline No & Jarak $(\mathrm{m})$ & Skor & Bobot & Skor $x$ Bobot \\
\hline 1 & $0-450$ & 1 & 10 & 10 \\
\hline 2 & $451-900$ & 2 & 10 & 20 \\
\hline 3 & $901-1350$ & 3 & 10 & 30 \\
\hline 4 & $1351-1800$ & 4 & 10 & 40 \\
\hline 5 & $1801-2250$ & 5 & 10 & 50 \\
\hline 6 & $>2550$ & 6 & 10 & 60 \\
\hline
\end{tabular}

Variasi wilayah daratan Kota Bandar Lampung berdasarkan jaraknya dari sungai-sungai utama yang berada di wilayah Kota Bandar Lampung sebagaimana disajikan pada Gambar 5.

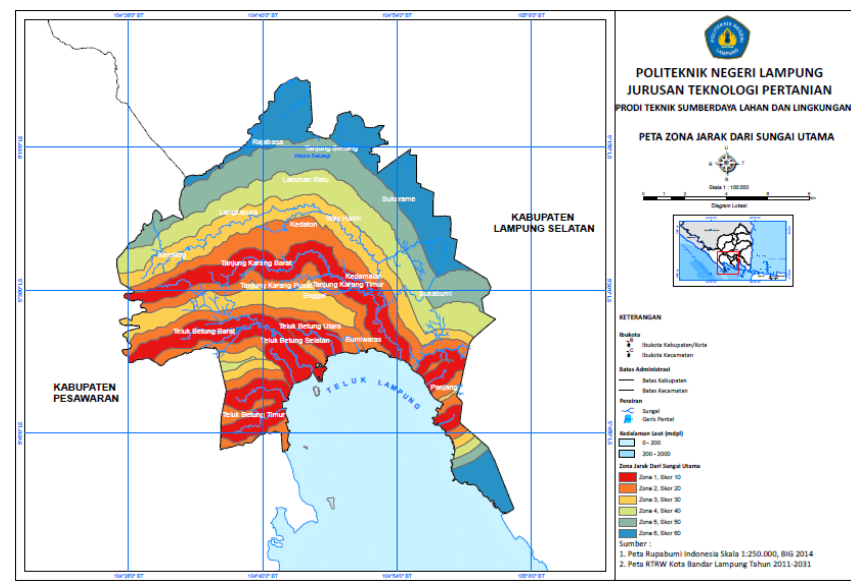

Gambar 5. Peta Tematik Skor x Bobot Berdasarkan Jarak dari Sungai Utama 
e. Keterlindungan Daratan

Kondisi keterlindungan daratan menjadi parameter penentu dalam menentukan zona rawan tsunami dengan bobot 15\%. Berdasarkan sumber yang diperoleh dari Subardjo, dkk. (2015) Klasifikasi perlindungan lahan dapat dilihat pada Tabel 6.

Tabel 6. Keterlindungan Daratan

\begin{tabular}{ccccc}
\hline No & Keterlindungan Daratan & Skor & Bobot & Skor $x$ Bobot \\
\hline 1 & Terbuka/Tidak Terlindung & 1 & 15 & 15 \\
\hline 2 & Terlindung & 2 & 15 & 30 \\
\hline
\end{tabular}

Secara umum wilayah daratan dan pesisir Kota Bandar Lampung tidak terlindung dari bahaya tsunami, sehingga skor total wilayah ini adalah 15 . Hasil peta tematik perlindungan lahan wilayah Kota Bandar Lampung menunjukkan bahwa pada Gambar 6.

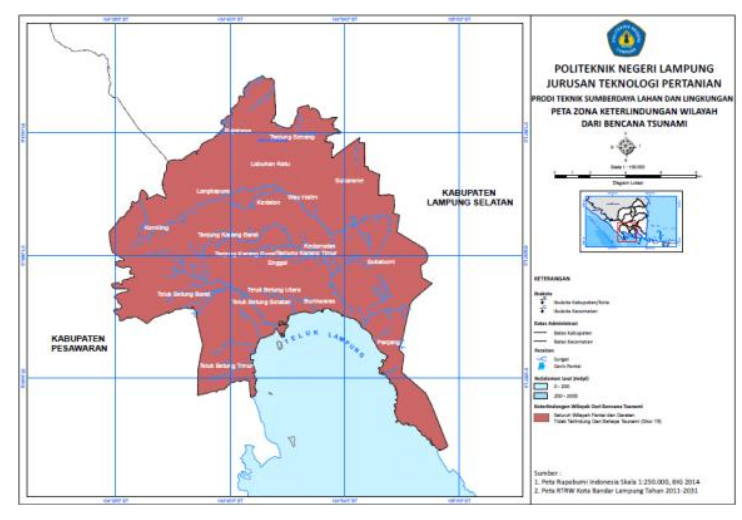

Gambar 6. Peta Tematik Skor x Bobot Berdasarkan Keterlindungan Daratan

\section{f. Keberadaan Pulau Penghalang}

Keberadaan pulau penghalang menjadi parameter penentu dalam penentuan zona bahaya tsunami dengan bobot 10\%. Berdasarkan sumber yang diperoleh dari Subardjo, dkk. (2015) Klasifikasi keberadaan pulau penghalang dapat dilihat pada Tabel 7.

Tabel 7. Keberadaan Pulau Penghalang

\begin{tabular}{ccccc}
\hline No & Keberadaan Pulau Penghalang & Skor & Bobot & Skor $x$ Bobot \\
\hline 1 & Tidak Ada & 1 & 10 & 10 \\
\hline 2 & Terdapat Pulau-Pulau Kecil & 2 & 10 & 20 \\
\hline
\end{tabular}

Di wilayah laut Teluk Lampung terdapat beberapa pulau kecil yang merupakan bagian dari bentangalam yang berfungsi untuk meminimalisis efek bahaya dari gelombang tsunami. Pulaupulau tersebut adalah Pulau Pahawang, Pulau Tegal, Pulau Pasaran, Pulau Kelagian, Pulau Tanjung Putus dan di depan sumber gempa ada Pulau Sebesi. Berdasarkan kondisi tersebut maka skor total keberadaan pulau penghalang adalah 20. Hasil peta tematik keberadaan pulau penghalang di wilayah Kota Bandar Lampung ditunjukkan pada Gambar 7.

140 Volume 12, Nomor 3 | Desember 2020:127-181 


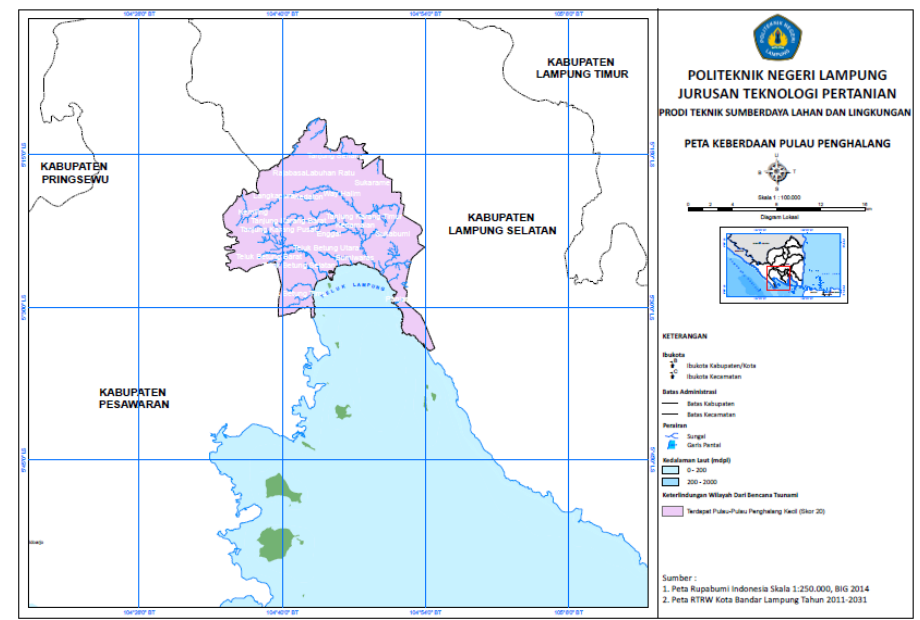

Gambar 7. Peta Tematik Skor x Bobot Berdasarkan Keberadaan Pulau Penghalang

\section{g. Morfologi Pantai}

Morfologi pantai menjadi parameter penentu dalam menentukan zona bahaya tsunami dengan bobot $10 \%$. Berdasarkan sumber yang diperoleh dari Subardjo, dkk. (2015) Klasifikasi morfologi pantai dapat dilihat pada Tabel 8 .

Tabel 8. Morfologi Pantai

\begin{tabular}{ccccc}
\hline No & Morfologi Pantai & Skor & Bobot & Skor $x$ Bobot \\
\hline 1 & Pantai Berteluk & 1 & 10 & 10 \\
\hline 2 & Pantai Tidak Berteluk & 2 & 10 & 20 \\
\hline
\end{tabular}

Pesisir kota Bandar Lampung merupakan bagian dari wilayah pesisir Teluk Lampung, oleh karena itu morfologi pantainya adalah pesisir teluk. Berdasarkan kondisi tersebut maka skor total untuk morfologi pantai adalah 10. Hasil skor peta tematik morfologi pantai di wilayah Kota Bandar Lampung ditunjukkan pada Gambar 8.

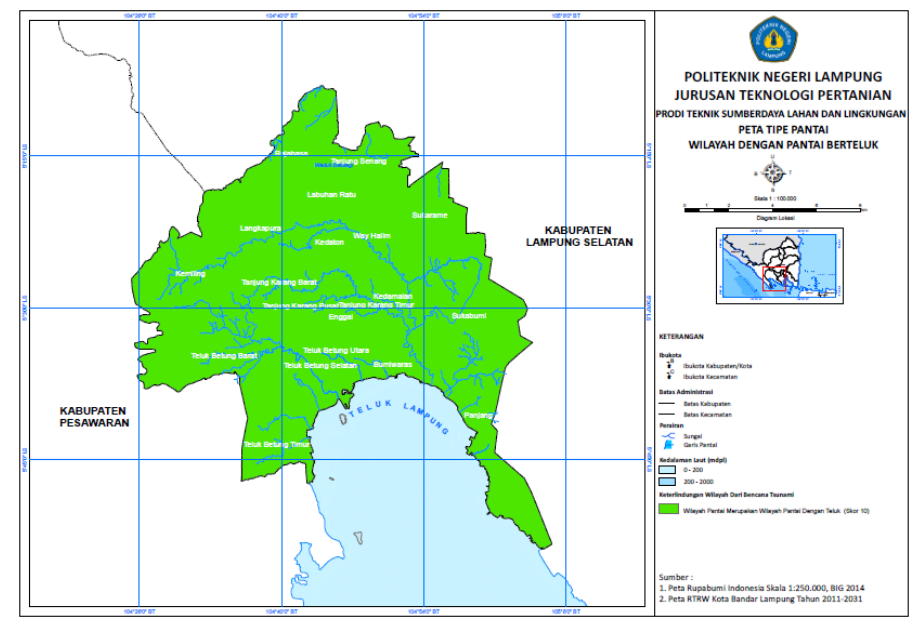

Gambar 8. Peta Tematik Morfologi Pantai 
h. Jarak dari Garis Pantai.

Jarak dari garis pantai menjadi parameter penentu dalam menentukan zona rawan tsunami dengan bobot 20\%. Berdasarkan sumber yang diperoleh dari Subardjo, dkk. (2015) Klasifikasi jarak dari garis pantai dapat dilihat pada Tabel 9.

Tabel 9. Jarak dari Garis Pantai

\begin{tabular}{ccccc}
\hline No & Jarak $(\mathrm{m})$ & Skor & Bobot & Skor $x$ Bobot \\
\hline 1 & $<556$ & 1 & 20 & 20 \\
\hline 2 & $557-1400$ & 2 & 20 & 40 \\
\hline 3 & $1401-2404$ & 3 & 20 & 60 \\
\hline 4 & $2405-3528$ & 4 & 20 & 80 \\
\hline 5 & $>3528$ & 5 & 20 & 100 \\
\hline
\end{tabular}

Berdasarkan identifikasi terhadap jarak dari garis pantai, wilayah daratan Kota Bandar Lampung seperti disajikan dalam peta tematik seperti pada Gambar 9.

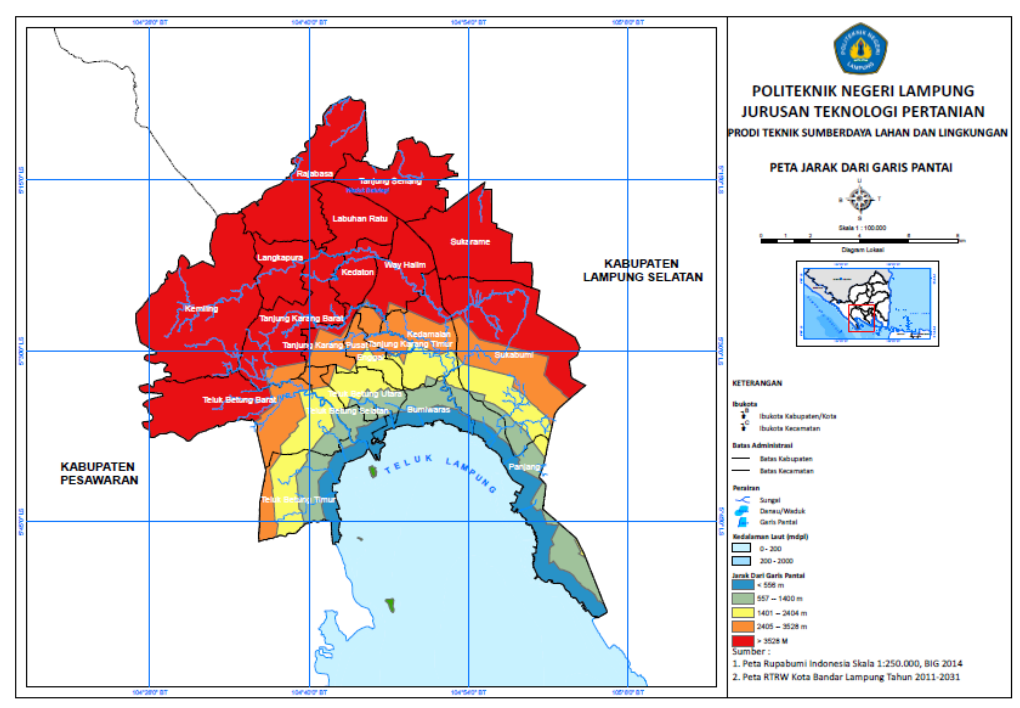

Gambar 9. Peta Tematik Jarak dari Garis Pantai

\section{HASIL DAN PEMBAHASAN}

Metode analisis geospasial yang digunakan adalah metode tumpang susun delapan peta tematik yang menjadi parameter penentu dalam pembuatan peta zona tsunami.

Berdasarkan sumber referensi yang digunakan sebagai dasar dalam menentukan zona kerentanan bahaya tsunami berdasarkan sumber yang diperoleh dari Subardjo, dkk. (2015), Klasifikasi Zona Rawan Tsunami dapat dilihat pada Tabel 10. 
Tabel 10. Klasifikasi Zona Kerentanan Tsunami

\begin{tabular}{clc}
\hline No & Zona Kerentanan & Skor $x$ Bobot (Total) \\
\hline 1 & Beresiko Sangat Tinggi & $>160$ \\
\hline 2 & Beresiko Tinggi & $161-225$ \\
\hline 3 & Agak Aman & $226-290$ \\
\hline 4 & Aman & $291--355$ \\
\hline 5 & Sangat Aman & $356--420$ \\
\hline
\end{tabular}

Berdasarkan analisis geospasial zona tsunami Kota Bandar Lampung diperoleh hasil bahwa Kota Bandar Lampung terbagi menjadi 4 kelas zona kerentanan tsunami. Rincian zona kerentanan tsunami Kota Bandar Lampung seperti pada Tabel 11.

Table 11. Tsunami Vulnerability Zone At Bandar Lampung City

\begin{tabular}{lcccc}
\hline No & Vulnerability Class & Total Skor & Luas $(\mathrm{Ha})$ & Persentase (\%) \\
\hline 1 & Beresiko Sangat Tinggi & $>160$ & $1.132,65$ & 5,74 \\
\hline 2 & Beresiko Tinggi & $161-225$ & $1.160,63$ & 5,88 \\
\hline 3 & Agak Aman & $226-290$ & $12.251,48$ & 62,12 \\
\hline 4 & Aman & $291--355$ & $5.177,24$ & 26,25 \\
\hline
\end{tabular}

Dari tabel di atas dapat dikatakan bahwa beberapa lokasi Kota Bandar Lampung di bagian selatan memiliki resiko bahaya tsunami yang tinggi hingga sangat tinggi, dengan luas wilayah sekitar 2.293,28 Ha.

Wilayah dengan kategori resiko bahaya tsunami sangat tinggi, terletak di bagian selatan Kota Bandar Lampung yaitu di Kecamatan Bumi Waras, Panjang, Sukabumi, Teluk Betung Barat, Teluk Betung Timur, Teluk Betung Utara dan Teluk Betung Selatan dengan detail area risiko sangat tinggi ditunjukkan pada Tabel 12.

Tabel 12. Luas Wilayah Kecamatan dengan Resiko Sangat Tingi

\begin{tabular}{clcc}
\hline No & \multicolumn{1}{c}{ Kecamatan } & Luas $(\mathrm{Ha})$ & Persentase (\%) \\
\hline 1 & Bumi Waras & 237,55 & 20,97 \\
\hline 2 & Panjang & 419,11 & 37 \\
\hline 3 & Sukabumi & 1,04 & 0,09 \\
\hline 4 & Teluk Betung Barat & 59,41 & 5,25 \\
\hline 5 & Teluk Betung Timur & 274,93 & 24,27 \\
\hline 6 & Teluk Betung Utara & 7,76 & 0,69 \\
\hline 7 & Teluk Betung Selatan & 132,84 & 11,73 \\
\hline
\end{tabular}

Wilayah dengan katagori risiko tinggi bahaya tsunami yang terletak di bagian selatan Kota Bandar Lampung yaitu di Kecamatan Bumi Waras, Panjang, Sukabumi, Teluk Betung Barat, Teluk Betung Timur, Teluk Betung Utara, Teluk Betung Selatan dan Kedamaian dengan detail resiko area yang ditunjukkan pada Tabel 13 . 
Tabel 13. Luas Wilayah Kecamatan dengan Resiko Tingi

\begin{tabular}{clcc}
\hline No & \multicolumn{1}{c}{ Kecamatan } & Luas $(\mathrm{Ha})$ & Persentase (\%) \\
\hline 1 & Bumi Waras & 160,66 & 13,84 \\
\hline 2 & Panjang & 421,12 & 36,28 \\
\hline 3 & Sukabumi & 60,38 & 5,20 \\
\hline 4 & Teluk Betung Barat & 91,04 & 7,84 \\
\hline 5 & Teluk Betung Timur & 153,54 & 13,23 \\
\hline 6 & Teluk Betung Utara & 174,82 & 15,06 \\
\hline 7 & Teluk Betung Selatan & 91,16 & 7,85 \\
\hline 8 & Kedamaian & 7,92 & 0,68 \\
\hline
\end{tabular}

Luas daerah dengan kategori agak aman dari bahaya tsunami yang terletak di seluruh wilayah Kota Bandar Lampung, dengan rincian daerah yang agak aman ditunjukkan pada Tabel 14.

Tabel 14. Luas Wilayah Kecamatan dengan Katagori Agak Aman

\begin{tabular}{rlrc}
\hline No & \multicolumn{1}{c}{ Kecamatan } & Luas $(\mathrm{Ha})$ & Persentase (\%) \\
\hline 1 & Bumi Waras & 50,78 & 0,41 \\
\hline 2 & Enggal & 296,85 & 2,42 \\
\hline 3 & Kedamaian & 878,88 & 7,17 \\
\hline 4 & Kedaton & 429,41 & 3,50 \\
\hline 5 & Kemiling & $1.392,51$ & 11,37 \\
\hline 6 & Labuhan Ratu & 492,91 & 4,02 \\
\hline 7 & Langkapura & 481,60 & 3,93 \\
\hline 8 & Panjang & 655,35 & 5,35 \\
\hline 9 & Rajabasa & 302,27 & 2,47 \\
\hline 10 & Sukabumi & $1.569,62$ & 12,81 \\
\hline 11 & Sukarame & 408,74 & 3,34 \\
\hline 12 & Tanjung Karang Barat & $1.116,52$ & 9,11 \\
\hline 13 & Tanjung Karang Pusat & 350,38 & 2,86 \\
\hline 14 & Tanjung Karang Timur & 223,52 & 1,82 \\
\hline 15 & Tanjung Senang & 229,20 & 1,87 \\
\hline 16 & Teluk Betung Barat & $1.607,07$ & 13,12 \\
\hline 17 & Teluk Betung Selatan & 146,23 & 1,19 \\
\hline 18 & Teluk Betung Timur & 696,03 & 5,68 \\
\hline 19 & Teluk Betung Utara & 279,82 & 2,28 \\
\hline 20 & Way Halim & 643,80 & 5,25 \\
\hline
\end{tabular}

Luas wilayah Kota Bandar Lampung dengan katagori aman dari bahaya tsunami yang terletak di bagian Utara Kota Bandar Lampung yaitu di Kecamatan Kedaton, Kemiling, Labuhan Ratu, Langkapura, Panjang, Rajabasa, Sukabumi, Sukarame, Tanjung Karang Barat, Tanjung Karang Pusat, Tanjung Senang dan Teluk Betung Barat dengan rincian wilayah aman dari bahaya tsunami ditunjukkan pada Tabel 15. 
Tabel 15. Luas Wilayah Kecamatan dengan Katagori Aman

\begin{tabular}{rlrc}
\hline No & \multicolumn{1}{c}{ Kecamatan } & Luas $(\mathrm{Ha})$ & Persentase (\%) \\
\hline 1 & Kedaton & 15,52 & $0,30 \%$ \\
\hline 2 & Kemiling & 913,36 & $17,64 \%$ \\
\hline 3 & Labuhan Ratu & 153,38 & $2,96 \%$ \\
\hline 4 & Langkapura & 87,47 & $1,69 \%$ \\
\hline 5 & Panjang & 5,77 & $0,11 \%$ \\
\hline 6 & Rajabasa & $1.129,57$ & $21,82 \%$ \\
\hline 7 & Sukabumi & $1.036,36$ & $20,02 \%$ \\
\hline 8 & Sukarame & 751,96 & $14,52 \%$ \\
\hline 9 & Tanjung Karang Barat & 156,10 & $3,02 \%$ \\
\hline 10 & Tanjung Karang Pusat & 16,52 & $0,32 \%$ \\
\hline 11 & Tanjung Senang & 747,10 & $14,43 \%$ \\
\hline 12 & Teluk Betung Barat & 146,00 & $2,82 \%$ \\
\hline
\end{tabular}

Hasil Peta Tematik Zona Kerentanan Tsunami di Kota Bandar Lampung ditunjukkan pada Gambar 10.

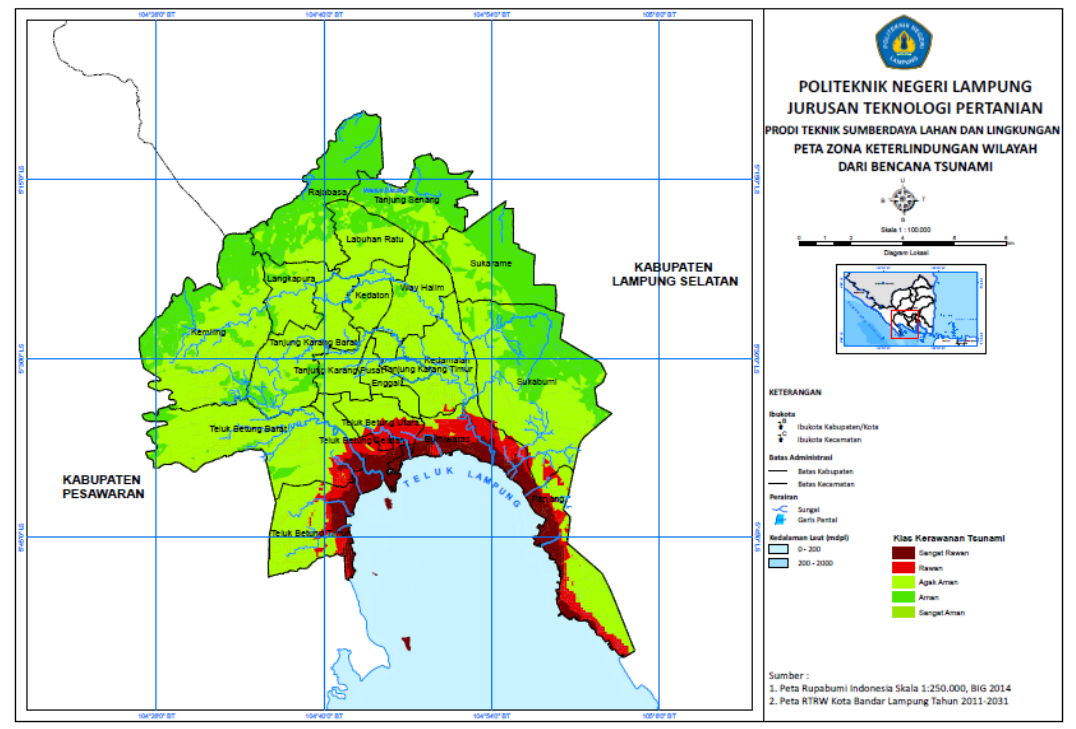

Gambar 10. Peta Tematik Zona Kerentanan Tsunami Kota Bandar Lampung

\section{Kesimpulan}

Di Kota Bandar Lampung terdapat beberapa Kecamatan yang rawan bencana tsunami dengan kategori resiko tinggi sampai dengan kategori resiko sangat tinggi.

Kecamatan dengan risiko tinggi hingga sangat tinggi berada di beberapa dari delapan kecamatan yang meliputi Kecamatan Bumi waras, Panjang, Sukabumi, Teluk Betung Barat, Teluk Betung Timur, Teluk Betung Utara, Teluk Betung Selatan dan Kedamaian dengan jumlah keseluruhan luasnya sekitar 2.293,28 Ha. 


\section{DAFTAR PUSTAKA}

Dewi C C, Armijon and Fadly R 2015 Analisis Pembuatan Peta Zona Rawan Bencana Tsunami Pada Daerah Pesisir”., Proseding Seminar Bisnis \& Teknologi, Lampung.

Santius S H 2015 Pemodelan Tingkat Risiko Bencana Tsunami Pada Permukiman Di Kota Bengkulu Enggunakan Sistem Informasi Geografis, Jurnal Permukiman Vol. 10 No. 2 November 2015 : $92-105$

Subardjo P and Ario R 2015 Uji Kerawanan Terhadap Tsunami dengan Sistem Informasi Geografis (SIG) Di Pesisir Kecamatan Kretek, Kabupaten Bantul, Yogyakarta Jurnal Kelautan Tropis September 2015 Vol. 18(2):82-97. 